\title{
Film Animasi “Nussa dan Rara Episode Baik Itu Mudah” sebagai Sarana Penanaman Karakter pada Anak Usia Dini
}

\author{
Octavian Muning Sayekti \\ Pendidikan Guru Sekolah Dasar, Fakultas Ilmu Pendidikan, Universitas Negeri Yogyakarta \\ Jalan Kolombo No 1, Caturtunggal, Depok, Sleman, Yogyakarta, Indonesia \\ E-mail: sayekti.octavian@uny.ac.id
}

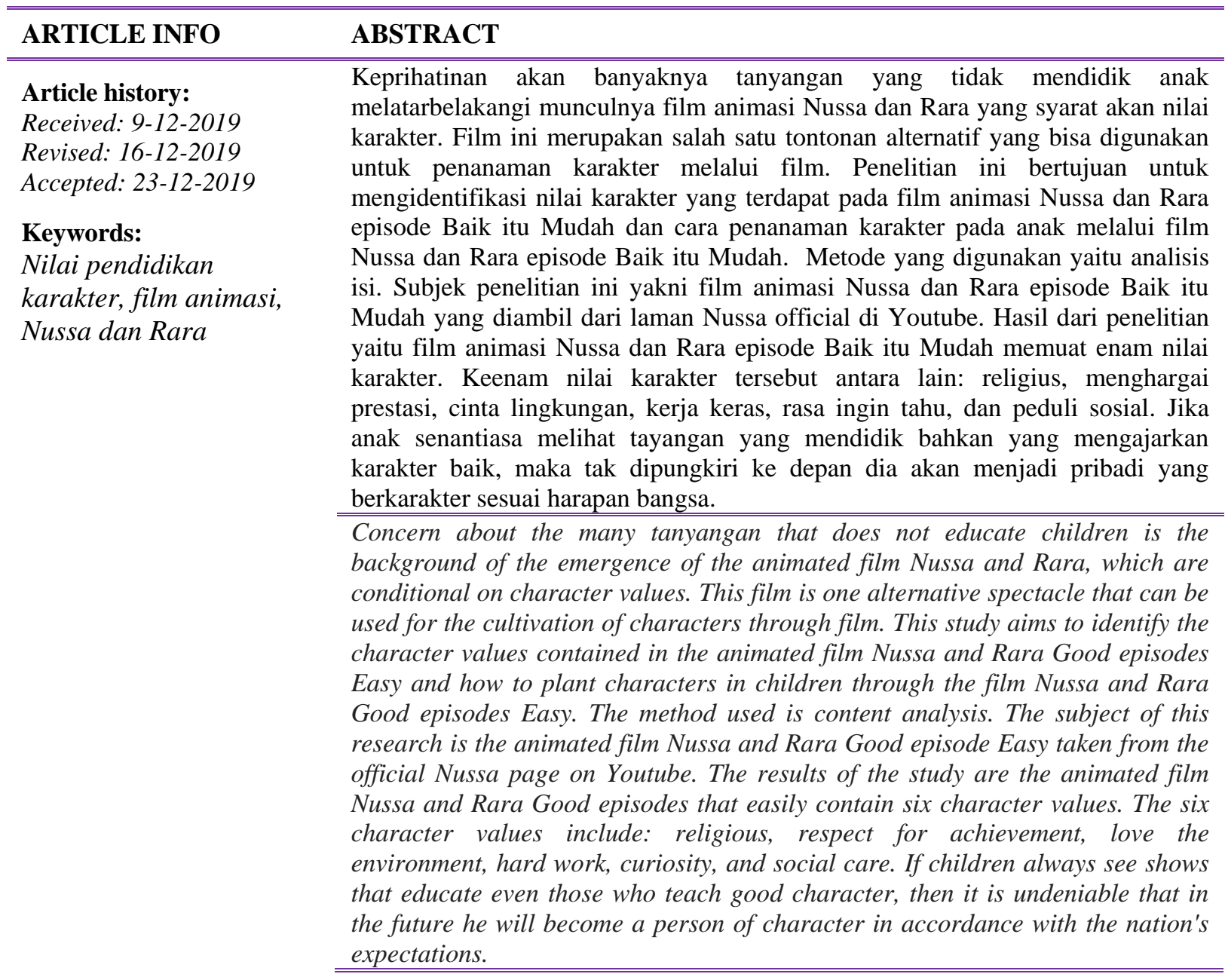

\section{PENDAHULUAN}

Pendidikan karakter di Indonesia sudah ditanamkan sejak satu dasawarsa ini. Berbicara mengenai pendidikan karakter tentu tidak ada habisnya. Pendidikan karakter harus diberikan kepada anak sejak dini. Anak yang memiliki karakter baik, maka akan berbanding lurus dengan pribadinya ke depan. Banyak permasalahn karakter yang melanda di negeri ini. Permasalahan karakter tersebut juga melanda di dunia pendidikan. Pernah terdengar berita guru dianiaya murid, bullying di sekolah, tindakan mencontek masal, atau pelecehan seksual yang dilakukan anak di bawah umur. Bahkan barubaru ini Indonesia dihebohkan dengan kasus Audry. Siswa SMP yang dianiaya oleh 12 siswa SMA. Sungguh miris keadaan anak Indonesia saat ini. Tentunya dengan berbagai kasus tersebut, timbul pertayaan. Ada apa dengan pendididikan karakter anak negeri?

Tak mengherankan jika saat ini pemerintah, menguatkan penanaman karakter dengan menyelipkannya ke dalam Kurikulum 2013. Pendidikan karakter tidak hanya menjadi tugas guru atau 
sekolah. Orang tua di rumah pun harus senantiasa menanamkan pendidikan karakter pada anaknya. Sejalan dengan Trilogi pendidikan yang menyebutkan bahwa pendidikan anak merupakan tanggung jawab keluarga, sekolah, dan masyarakat. Karakter merupakan ciri dasar yang dimiliki oleh masingmasing individu. Pendidikan karakter merupakan proses untuk menumbuhkan kesadaran pada tiap individu. Kesadaran yang dimaksud yaitu kesadaran sebagai bangsa yang bermartabat, merdeka, dan berdaulat serta memiliki kemauan untuk menjaga dan mempertahankan kemerdekaan (Zuchdi, 2009: 154). Dikatan pula oleh Samani dan Hariyanto (2010: 43) bahwa karakter merupakan nilai dasar yang membangun pribadi seseorang terbentuk baik karena pengaruh hereditas maupun pengaruh lingkungan yang membedakannya dengan orang lain serta diwujudkan dalam sikap dan perilakunya dalam kehidupan sehari-hari. Senada dengan hal tersebut Wijayanti dan Wachid (2019: 274 )mengatakan bahwa karakter adalah nilai-nilai yang harus diajarkan meliputi nilai-nilai kehidupan, baik yang termasuk dalam nilai moralitas, nilai kebaikan, nilai religius, dan nilai kewarganegaraan. Adapun pendidikan karakter adalah proses transformasi nilai-nilai kehidupan untuk membina karakter yang bersifat nondeterministik agar menjadi seseorang yang berkarakter baik dalam keingintahuan yang baik, menginginkan hal yang baik, dan berbuat baik dalam kehidupan sehari-hari. Dari pendapat mengenai pendidikan karakter tersebut, dapat disimpulkan bahwa pendidikan karakter merupakan sebuah proses perubahan untuk mewujudkan nilai-nilai baik dalam kehidupan sehari-hari. Tujuan pendidikan karakter yaitu pendidikan karakter adalah untuk mengajarkan nilai-nilai tradisional tertentu, nilai-nilai yang diterima secara menyeluruh digunakan sebagai landasan perilaku yang baik dan bertanggungjawab (Zuchdi, 2009: 39). Ada 18 pilar karakter yang dikembangkan oleh Depdiknas (Kemendiknas, 2010: 9-10). Kedelapan belas pilar karakter itu antara lain:

Negara Indonesia sendiri terdapat 18 karakter yang telah ditetapkan oleh pemerintah, yaitu sebagai berikut.

Tabel 1. Nilai dan Deskripsi Nilai Pendidikan Budaya dan Karakter Bangsa

\begin{tabular}{|c|c|c|}
\hline No & Karakter & Deskripsi \\
\hline 1 & Religius & Sikap dan perilaku yang patuh dalam melaksanakan ajaran agama yang dianutnya \\
\hline 2 & Jujur & $\begin{array}{l}\text { Perilaku yang didasarkan pada upaya menjadikan dirinya sebagai orang yang selalu dapat } \\
\text { dipercaya dalam perkataan, tindakan, dan pekerjaan. }\end{array}$ \\
\hline 3 & Toleransi & $\begin{array}{l}\text { Sikap dan tindakan yang menghargai perbedaan agama, suku, etnis, pendapat, sikap, dan } \\
\text { tindakan orang lain yang berbeda dari dirinya. }\end{array}$ \\
\hline 4 & Disiplin & Tindakan yang menunjukkan perilaku tertib dan patuh pada berbagai ketentuan dan peraturan. \\
\hline 5 & Kerja keras & $\begin{array}{l}\text { Perilaku yang menunjukkan upaya sungguh-sungguh dalam mengatasi berbagai hambatan } \\
\text { belajar dan tugas, serta menyelesaikan tugas dengan sebaik-baiknya. }\end{array}$ \\
\hline 6 & Kreatif & $\begin{array}{l}\text { Berpikir dan melakukan sesuatu untuk menghasilkan cara atau hasil baru dari sesuatu yang telah } \\
\text { dimiliki. }\end{array}$ \\
\hline 7 & Mandiri & $\begin{array}{l}\text { Sikap dan perilaku yang tidak mudah tergantung pada orang lain dalam menyelesaikan tugas- } \\
\text { tugas. }\end{array}$ \\
\hline 8 & Demokratis & $\begin{array}{l}\text { Cara berfikir, bersikap, dan bertindak yang menilai sama hak dan kewajiban dirinya dan orang } \\
\text { lain. }\end{array}$ \\
\hline 9 & Rasa ingin tahu & $\begin{array}{l}\text { Sikap dan tindakan yang selalu berupaya untuk mengetahui lebih mendalam dan meluas dari } \\
\text { sesuatu yang dipelajarinya, dilihat, dan didengar. }\end{array}$ \\
\hline 10 & $\begin{array}{l}\text { Semangat } \\
\text { kebangsaan }\end{array}$ & $\begin{array}{l}\text { Cara berpikir, bertindak, dan berwawasan yang menempatkan kepentingan bangsa dan negara di } \\
\text { atas kepentingan diri dan kelompoknya. }\end{array}$ \\
\hline 11 & Cinta tanah air & $\begin{array}{l}\text { Cara berfikir, bersikap, dan berbuat yang menunjukkan kesetiaan, kepedu-lian, dan penghargaan } \\
\text { yang tinggi terhadap bahasa, lingkungan fisik, sosial, budaya, ekonomi, dan politik bangsa. }\end{array}$ \\
\hline 12 & $\begin{array}{l}\text { Menghargai } \\
\text { prestasi }\end{array}$ & $\begin{array}{l}\text { Sikap dan tindakan yang mendorong dirinya untuk menghasilkan sesuatu yang berguna bagi } \\
\text { masyarakat, dan mengakui, serta menghormati keberhasilan orang lain. }\end{array}$ \\
\hline 13 & $\begin{array}{l}\text { Bersahabat/ } \\
\text { Komunikatif }\end{array}$ & $\begin{array}{l}\text { Tindakan yang memperlihatkan rasa senang berbicara, bergaul, dan bekerja sama dengan orang } \\
\text { lain. }\end{array}$ \\
\hline 14 & Cinta damai & $\begin{array}{l}\text { Sikap, perkataan, dan tindakan yang menyebabkan orang lain merasa senang dan aman atas } \\
\text { kehadiran dirinya. }\end{array}$ \\
\hline 15 & Gemar membaca & $\begin{array}{l}\text { Kebiasaan menyediakan waktu untuk membaca berbagai bacaan yang memberikan kebajikan } \\
\text { bagi dirinya. }\end{array}$ \\
\hline 16 & Peduli lingkungan & $\begin{array}{l}\text { Sikap dan tindakan yang selalu berupaya mencegah kerusakan pada lingkungan alam di } \\
\text { sekitarnya, dan mengembangkan upaya-upaya untuk memperbaiki kerusakan alam yang sudah } \\
\text { terjadi. }\end{array}$ \\
\hline 17 & Peduli sosial & $\begin{array}{l}\text { Sikap dan tindakan yang selalu ingin memberi bantuan pada orang lain dan masyarakat yang } \\
\text { membutuhkan. }\end{array}$ \\
\hline 18 & Tanggung jawab & $\begin{array}{l}\text { Sikap dan perilaku seseorang untuk melaksanakan tugas dan kewajibannya, yang seharusnya dia } \\
\text { lakukan, terhadap diri sendiri, masyarakat, lingkungan (alam, sosial dan budaya), negara dan } \\
\text { Tuhan Yang Maha Esa. }\end{array}$ \\
\hline
\end{tabular}

Sumber : Kemendiknas.(2010). Pedoman Pendidikan Budaya Karakter Bangsa.

Jakarta: Balitbang Pusat Kurikulum dan Perbukuan. Hal 9-10. 
Banyak cara yang bisa dilakukan oleh orang tua untuk melakukan pembiasaan nilai karakter di rumah. Misalnya mengajak anak untuk gemar membaca buku, menceritakan dongeng anak, mengajak anak untuk cinta lingkungan, dan masih banyak lagi. Penanaman karakter bisa juga dilakukan melalui sastra anak. Melalui sastra, anak bisa diajarkan nilai baik dan buruk. Dalam sastra anak bisa dikenalkan perbuatan yang patut untuk ditiru dan tidak patut untuk ditiru. Salah satu sastra yang bisa digunakan untuk pembejaran nilai karakter yaitu cerita anak. Cerita saat ini dimodifikasi dalam bentuk film animasi. Film animasi tersebut bisa dinikmati di televisi atau media lain yang mendukung.

Di Indonesia, banyak acara yang menyuguhkan tayangan untuk anak. Namun, sebagai orang tua harus mampu menjadi filter. Jangan sampai anak salah menikmati siaran televisi yang tidak ada nilai karakternya atau malah akan merusak moral anak. Mengingat karakteristik anak adalah meniru. Seorang anak akan lebih mudah merekam kejadian yang dilihat kemudian mereka tirukannya di dunia nyata. Misalnya ketika anak suka menonton acara televisi yang memuat tindakan kekerasan. Maka tidak mengherankan jika suatu saat anak akan meniru dan menerapkannya kepada adik atau teman mereka. Oleh karena itu, sangat lah berhati-hati ketika memilihkan tayangan untuk anak.

Jika diamati, tayangan televisi dan dunia maya yang dikhususkan untuk anak, belakangan ini sangat minim yang memuat nilai karakter. Jika dibandingkan pada era 1990-an sangat jauh. Di massa tersebut, walaupun belum mengenal internet namun tayangan televisi yang dikhusukan untuk anak sangat beragam. Mulai dari lagu anak-anak, film animasi, ataupun acara yang lain yang memang peruntukkannya untuk anak. Jika saat ini, tayangan televisi lebih dihiasi dengan acara sinetron maupun acara reality show yang tidak ada unsur karakternya sama sekali. Alih-alih mengajarkan nilai karakter, tayangan tersebut justru mengajarkan kekerasan kepada anak.

Film animasi adalah salah satu media yang bisa digunakan untuk menanamkan nilai karakter. Film merupakan salah satu media komunikasi modern yang efektif untuk menghibur sekaligus menyampaikan pesan yang dapat mempengaruhi sikap, pola pikir dan membuka wawasan bagi para penonton (Widyatmoko, Edy, T., S, Sugeng N., 2019: 74). Di Indonesia, banyak ditayangkan film animasi anak. Baik itu tayang di televisi maupun di chanel youtube. Beberapa film animasi yang diperuntukkan untuk anak misalnya Sopo Jarwo, Nussa dan Rara, Diva the Series, Upin-Ipin, dan lainlain.

Film animasi Nussa dan Rara diproduksi oleh rumah animasi The Little Giantz yang di gagas oleh Mario Irwinsyah dengan kolaborasi bersama 4 Stripe Production. Ada hal menarik yang ditampilkan pada film tersebut. Karakter Nussa digambarkan dengan sosok anak laki-laki berusia 10 tahun mengenakan baju koko dan peci putih. Tokoh Nussa merupakan anak laki-laki yang menyandang disabilitas sejak lahir. Salah satu kakinya cacat dan mengharuskan dia memakai kaki palsu. Kemudian tokoh Rara digambarkan sebagai anak perempuan kecil yang memakai gamis dan terlihat lucu menggemaskan.

Film ini lahir dilatarbelakangi oleh kemerosotan arakter anak bangsa. Film animasi Nussa dan Rara merupakan film besutan sutradara Bonny Wirasmono baru mulai ditayangkan sekitar bulan Desember 2018. Film tersebut baru bisa dinikmati melalui channel youtube. Walaupun baru beberapa minggu ditayangkan, viewer-nya langsung berjumlah ratusan ribu. Dilansir dari Tribunnews.com bahwa film tersebut mendapat sambutan baik dari masyarakat Indonesia, episode perdana dari Nussa Official kini telah disaksikan oleh 2,2 juta penonton dan memiliki 400 ribu lebih subscriber. Bahkan, menduduki posisi trending 3 di YouTube Indonesia.

Hal tersebut dikarenakan film animasi yang ditayangkan di Indonesia masih jarang yang memuat nilai karakter. Film animasi Nusaa dan Rara seakan menjawab kehausan masyarakat akan pendidikan karakter yang terkandung dalam sebuah film animasi. Berdasarkan penelilitian Demillah (2019: 107) menyimpulkan bahwa film animasi Nussa dan Rara memberikan pengajaran atau ilmu yang bermanfaat bagi anak. Film yang seperti inilah yang baik untuk dikonsumsi anak-anak. Penelitian ini akan menganalisis nilai karakter yang terdapat pada film Nussa dan Rara serta relevansinya dalam pembelajaran di sekolah dasar.

\section{METODE}

Metode dalam penelitian ini adalah analisis isi (content analysis). Karena dalam penelitian ini akan membahasa secara mendalam kalimat dan adegan dalam film animasi. Seperti yang dikemukakan oleh Eriyanto (2011: 64) mengatakan bahwa dalam metode analisis isi yang disebut sebagai unit analisis adalah bagian dari isi yang akan diamati, dapat berupa kata, kalimat, gambar, potongan 
adegan, paragraf, dan sebaginya. Begitu juga disampaikan oleh Krippendorff (1980: 21) analisis konten. Data penelitian yaitu film animasi Nussa dan Rara episode "Baik itu Mudah" yang disutradarai Bonny Wirasmono. Objek penelitian yaitu nilai karakter yang terkandung dalam film animasi Nussa dan Rara episode "Baik itu Mudah". Selain menganalisis nilai karakter yang terkandung dalam film tersebut, penelitian ini juga membahas bagaimana penanaman karakter untuk anak melalui film animasi Nussa dan Rara. Pada penelitian ini unit yang akan dianalisis yaitu dialog dan adegan yang ditayangkan dalam film. Dialoh-dialog tersebut didata kemudian dianalisis nilai karakter yang ada. Setelah nilai-nilai karakter diidentifikasi kemudian didesriptifkan secara mendalam. Adapun instrumen yang dipakai yaitu peneliti sendiri. Teknik analisis data menggunakan deskriptif kualitatif.

\section{HASIL DAN PEMBAHASAN}

\section{Hasil}

Film animasi Nussa dan Rara merupakan salah satu tontonan yang mendidik. Film ini merupakan salah satu tontonan yang bisa digunakan untuk pembelajaran karakter pada anak. mengingat dalam film ini memasukkan pendidikan karakter yang sangat baik jika hal tersebut diperkenalkan kepada anak sejak usia dini. Berikut hasil identifikasi nilai karakter yang ada pada film animasi Nussa dan Rara episode Baik itu Mudah.

Tabel 2. Nilai karakter yang ada dalam film animasi Nussa dan Rara episode Baik itu Mudah

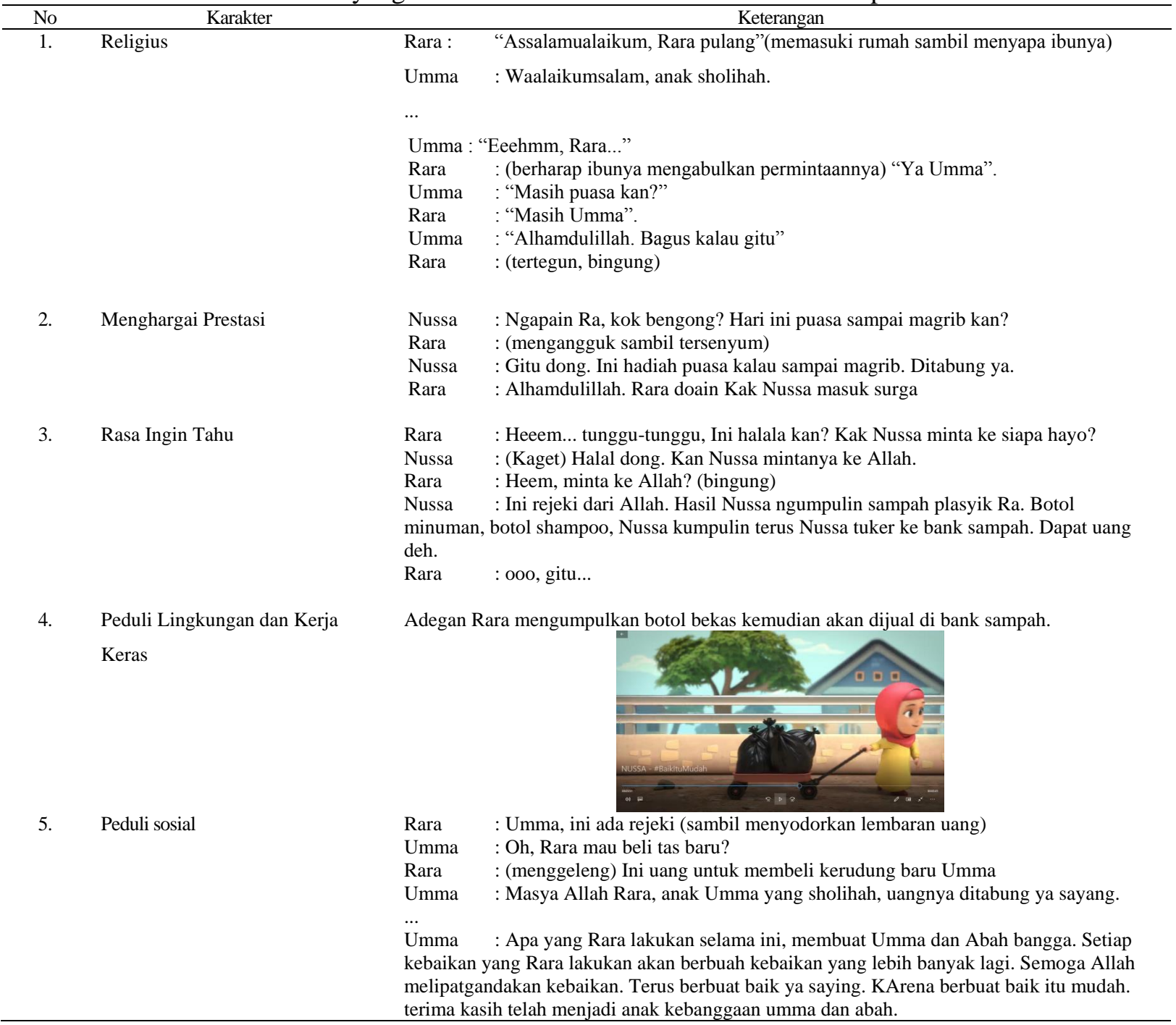

\section{Pembahasan}

Film animasi Nussa dan Rara yang sudah mendunia di kalangan masyarakat Indonesia sejak 
tahun 2018 kemarin ternyata memiliki beberapa nilai karakter yang bisa diaplikasikan untuk pendidikan anak. Berikut akan dipaparkan hasil analisis nilai karakter yang terdapat pada film animasi Nussa dan Rara episode Baik Itu Mudah.

1. Religius

Rara : “Assalamualaikum, Rara pulang”(memasuki rumah sambil menyapa ibunya)

Umma : Waalaikumsalam, anak sholihah.

(Baik itu Mudah, 1:15-1:25)

Penggalan dialog tersebut, menggambarkan bahwa sosok Rara dan Umma memiliki karakter religius. Karakter religius diantara keduanya ditunjukkan dengan mengucapkan salam, Assalamualaikum. Ucapan salam seperti itu adalah ucapan salam umat muslim jika berjumpa dengan umat muslim lainnya. Hukum mengucapkan salam dalam agama Islam adalah sunnah, sedangkan orang yang mendengar wajib menjawabnya. Dalam dialog tersebut, terlihat bahwa tokoh Umma menjawab dengan jawaban waalaikumsalam. Dalam Islam, manusia wajib salang bertegur sapa maupun mengucapkan salam ketika bertemu. Ucapan salam tersebut tidak hanya digunakan untuk menyapa, namun juga saling mendoakan. Assalamualaikum jika diterjemahkan memiliki makna semoga keselamatan terlimpah untukmu. Kalimat ini adalah do'a dan Sunnah yang diajarkan oleh Rasulullah SAW. Ketika memberi salam artinya kita mendo'akan sesama muslim dengan kebaikan berupa keselamatan dunia akhirat, rahmat dan juga segala bentuk keberkahan dari Allah SWT.

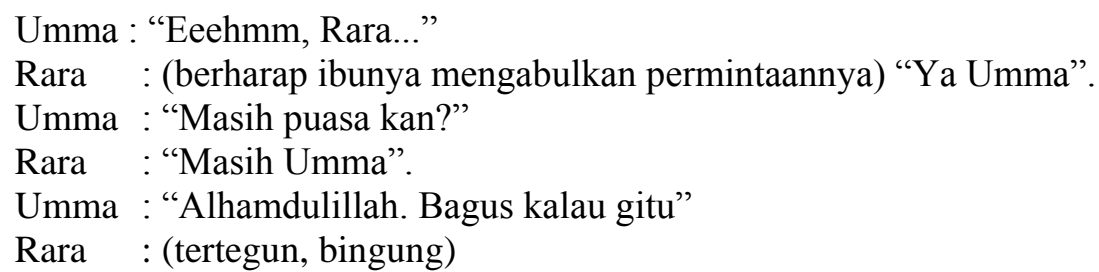

(Baik itu Mudah, 1:44-1:55)

Pada penggalan dialog di atas, nilai religius juga nampak pada saat Umma menanyakan apakah anaknya masih puasa atau sudah batal. Dalam agama Islam, puasa di bulan Ramadhan wajib hukumnya bagi mereka yang sudah dewasa (baligh). Walaupun tokoh Rara digambarkan masih berusia sekolah dasar, namun tidak ada salahnya jika orang tua mengajarkan dan mengenalkan puasa kepada anak mereka. Hal ini menggambarkan bahwa keluarga Rara memiliki tingkat religius tinggi.

\section{Menghargai Prestasi}

Nilai karakter menghargai prestasi ditunjukkan pada penggalan dialog di bawah ini.

Nussa : Ngapain Ra, kok bengong? Hari ini puasa sampai magrib kan?

Rara : (mengangguk sambil tersenyum)

Nussa : Gitu dong. Ini hadiah puasa kalau sampai magrib. Ditabung ya.

Rara : Alhamdulillah. Rara doain Kak Nussa masuk surga

(Baik itu Mudah, 2:15-2:34)

Dari penggalan dialog di atas, tampak bahwa tokoh Nussa memikii sikap menghargai prestasi adiknya, Rara. Nussa menghargai prestasi adiknya yang telah berlatih untuk puasa. Walaupun usia Rara masih belum dewasa dan belum wajib untuk puasa. Cara yang dilakukan oleh Nussa untuk menghargai prestasi adiknya adalah dengan memberikan hadiah berupa uang. Pemberian hadiah ini akan memeberikan semangat kepada adiknya. Harapannya, dengan tindakan menghargai prestasi yang dilakukan oleh Nussa, adiknya akan lebih semangat dalam menjalankan ibadah puasa. Selain mengandung nilai menghargai prestasi, penggalan di atas juga mengandung nilai religius. Seperti apa yang telah dijelaskan di paragraf sebelumnya.

3. Rasa Ingin Tahu

Rara : Heeem... tunggu-tunggu, Ini halal kan? Kak Nussa minta ke siapa hayo?

Nussa : (Kaget) Halal dong. Kan Nussa mintanya ke Allah.

Rara : Heem, minta ke Allah? (bingung)

Nussa : Ini rejeki dari Allah. Hasil Nussa ngumpulin sampah plasyik Ra. Botol minuman,

botol shampoo, Nussa kumpulin terus Nussa tuker ke bank sampah. Dapat uang deh. 


$$
\text { Rara : ooo, gitu... }
$$

(Baik itu Mudah, 2:38-3:05)

Nilai rasa ingin tahu didefinisikan sebagai sikap dan tindakan yang selalu berupaya untuk mengetahui lebih mendalam dan meluas dari sesuatu yang dipelajarinya, dilihat, dan didengar. Adapun dalam film animasi Nussa dan Rara Episode Baik itu Mudah, juga mengandung nilai karakter rasa ingin tahu. Nilai rasa ingin tahu dalam film tersebut, ditunjukkan pada dialog di atas. Tokoh Rara memiliki upaya mengetahui lebih mendalam terhadap uang yang diberikan oleh Nussa. Rara menanyakan dari mana uang tersebut. Tokoh Rara juga menunjukkan rasa ingin tahu, ketika Nussa mengatakan bahwa uang yang ia berikan didapat dari Allah. Secara konkrit, Allah tentu tidak akan secara langsuang m,emberikan uang kepada manusia. Allah akan memeberikan rezki melalui perantara. Oleh karena itu, Rara merasa bingung dengan jawaban Nussa lalu berusaha mencari tahu lebih dalam mengapa uang tersebut diberi oleh Allah.

4. Peduli Lingkungan dan Kerja Keras

Nilai karakter peduli lingkungan dan kerja kerasr, tidak ada di dalam dialog di film tersebut. Namun nilai peduli lingkungan dan kerja keras, ditampilkan dalam bentuk adegan adegan yang menggambarkan tokoh Rara melakukan kegiatan mengumpulkan sampah plastik yang akan dijual ke bank sampah. Adegan tersebut nampak pada potongan-potongan gambar di bawah ini.

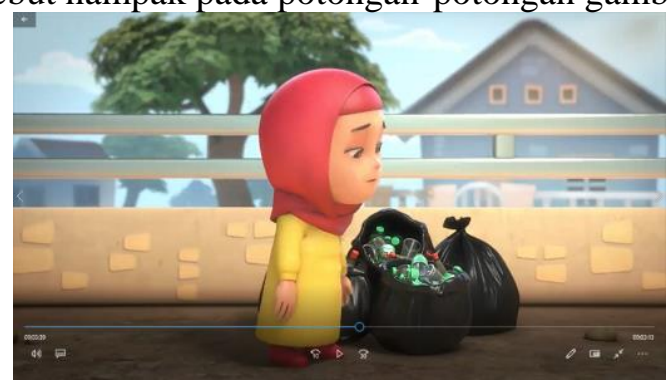

Gambar 1. Rara sedang mengumpulkan sampah plastic (Baik itu Mudah, 3:38)

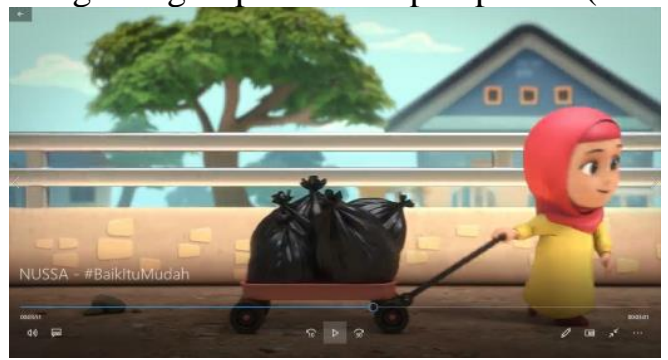

Gambar 2. Rara menarik bungkusan yang berisi sampah dan akan dia jual ke bank sampah (3:54)

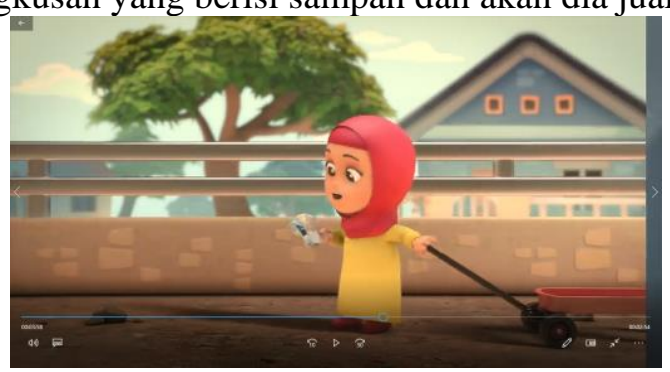

Gambar 3. Rara memperoleh uang hasil menjual botol bekas (Baik itu Mudah, 3:58)

Adegan di atas, menggambarkan tokoh Rara memiliki karakter peduli lingkungan. Memunguti botol plastik baik itu botol minuman, botol kecap, dan lain-lain. botol-botol tersebut ia kumpulkan ke dalam plastik besar yang akan ia jual ke bank sampah. Tentulah kegiatan tersebut menggambarkan nilai peduli lingkungan. Karena dengan lingkungan yang bebas dari sampah, maka lingkungan akan sehatt dan nyaman. Lingkungan akan terhindar dari sarang penyakit dan banjir. Selain nilai peduli lingkungan, adegan tersebut juga menggambarkan nilai kerja keras. Tokoh Rara berusaha dengan sungguh-sungguh untuk mengumpulkan sampah hari demi hari. Sampah tersebut akan ia jual ke bank sampah. Tidak ada rasa putus asa maupun malas. Usahanya juga tidak sia-sia, karena dia mendapatkan uang yang jumlahnya lebi dari cukup. 


\section{Peduli Sosial}

Rara : Umma, ini ada rejeki (sambil menyodorkan lembaran uang)

Umma : Oh, Rara mau beli tas baru?

Rara : (menggeleng) Ini uang untuk membeli kerudung baru Umma

Umma : Masya Allah Rara, anak Umma yang sholihah, uangnya ditabung ya sayang.

(Baik itu Mudah, 4:32-4:55)

Peduli sosial merupakan sikap dan tindakan yang selalu ingin memberi bantuan pada orang lain dan masyarakat yang membutuhkan. Penggalan dialog di atas, menunjukkan nilai peduli sosial yang dilakukan oleh Rara. Dia berniat untuk membelikan kerudung baru ibunya. Rara memiliki niat seperti itu, karena kerudung yang dipakai ibunya hanya satu. Sikap yang dimiliki Rara ini juga termasuk wujud kasih saying seorang anak terhadap ibunya. Anak, sedari dini memang harus diajarkan nilai peduli sosial. Agar kelak, ia tumbuh menjadi pribadi yang memiliki empati tinggi terhadap sesama. Selalu berusaha meringankan penderitaan orang lain. Hal senada juga nampak pada dialog lain di episode tersebut.

Umma : Apa yang Rara lakukan selama ini, membuat Umma dan Abah bangga. Setiap kebaikan yang Rara lakukan akan berbuah kebaikan yang lebih banyak lagi. Semoga Allah melipatgandakan kebaikan. Terus berbuat baik ya saying. Karena berbuat baik itu mudah. terima kasih telah menjadi anak kebanggaan umma dan abah.

(Baik itu Mudah, 5:40-5:58)

Kutipan dialog Umma di atas juga mengandung nilai peduli sosial. Tokoh Rara yang masih duduk di bangku sekolah dasar berusaha melakukan perbuatan yang membantu masyarakat sekitar. Dia melakukan kegiatan memunguti sampah plastic kemudia menjualnya ke bank sampah. Perilaku seperti itu tentu akan membuat lingkungan menjadi terbebas dari sampah.

\section{Film Animasi Nussa dan Rara sebagai Sarana Penanaman Karakter pada Anak Usia Dini}

Penanaman karakter pada anak tentu ada tahapannya. Sama halnya ketika seorang anak belajar hal umum. Belajar tentulah membutuhkan proses atau tahapan. Seseorang yang belajar tidak akan langsung mampu melakukan apa yang menjadi tujuannya. Di sini, peran guru dan orang tua sangat lah penting dalam mendampingi anak untuk mencapai tujuan yaitu berupa nilai karakter.

Penanaman pendidikan karakter pada anak bisa dilakukan dengan proses Tringo (Ngerti, Ngroso, Nglakoni). Ki Hadjar Dewantara berpendapat bahwa terhadap segala ajaran hidup, cita-cita hidup yang kita anut diperlukan pengertian, kesadaran dan kesungguhan pelaksanaannya. Tahu dan mengerti saja tidak cukup, kalau tidak merasakan menyadari, dan tidak ada artinya kalau tidak melaksanakan dan tidak memperjuangkannya (Wardhani, 2010: 235). Ngerti jika diterjemahkan ke dalam Bahasa Indonesia adalah mengerti. Mengerti artinya menangkap (memahami, tahu) apa yang dimaksud oleh sesuatu. Ngroso dimaknai sebagai merasa. Merasakan yaitu yang terasa dalam hati, yang terkandung di dalam hati. Nglakoni diartikan sebagai melakukan. Melakukan artinya mengerjakan (menjalankan dan sebagainya).

Dalam hal ini, ketika anak menonton tayangan film animasi Nussa dan Rara mereka diajak untuk mengerti dan memahami nilai apa yang termuat di dalam cerita tersebut. Di sinilah pentingnya peran pendamping. Guru ataupun orang tua sebagai pendamping mereka di rumah maupun sekolah, hendaklah jeli dalam memahamkan nilai-nilai karakter yang dimunculkan pada film tersebut. Setelah anak sudah memahami nilai apa yang dimunculkan dari film tersebut maka anak diajak untuk merasakan dan mneyadari nilai yang terkadung di dalam film tersebut, hal ini bisa dilakukan dengan cara anak diposisikan jika berada pada posisi Rara. Tak hanya berhenti samapi di situ, anak juga diharapkan mampu melaksanakan dan menjalankan. Tindakan apa yang telah dilakukan oleh tokoh Rara, diharapkan bisa menjadi keteladanan untuk anak.

Film merupakan salah satu media penanaman karakter untuk anak. Anak yang notabene senang dengan dunia imajinasi tentunya akan menyukai film yang di dalamnya mengisahkan cerita kehidupan manusia. Film ternyata mampu menularkan atmosfir positif bahkan menanamkan pendidikan karakter. Film-film yang sarat akan nilai inilah yang bisa diguankan untuk pembelajaran di sekolah. Guru dan orang tua hendaklah menjadi pendamping dan fasilitator yang baik. Mereka harus selektif dalam memilih dan memilah tontonan untuk anak. 


\section{SIMPULAN}

Berdasarkan paparan di awal dapat diambil beberapa kesimpulan antara lain:

1. Film animasi Nussa dan Rara yang berjudul "Baik itu Mudah" merupakan salah satu alternative tontonan untuk anak. Karena film tersebut memiliki beberapa nilai karakter yang tentunya sangat baik jika diterapkan pada anak. Nilai-nilai karakter tersebut antara lain: religius, peduli sosial, rasa ingin tahu, peduli lingkungan, kerja keras, dan menghargai prestasi.

2. Setelah menonton film Nussa dan Rara tersebut, orang tua dan guru bisa melakukan penanaman pendidikan karakter salah satunya adalah dengan Tri Ngo. Ngerti-NgrosoNglakoni. Setelah anak mengerti apa makna dari film tersebut, mereka kemudian diajak untuk meresapi makna yang lebih dalam. Kemudian yang terakhir mereka diajak untuk menerapkan dalam kehidupan sehari-hari.

\section{DAFTAR PUSTAKA}

Eriyanto. (2011). Analisis isi: pengantar metodologi untuk penelitia ilmu Komunikasi dan Ilmu-ilmu Sosial Lainnya. Jakarta: Kencana.

Demillah, A. (2019) Peran film animasi nussa dan rara dalam meningkatkan pemahaman tentang ajaran islam pada pelajar SD. Jurnal Interaksi. Vol. 3, No 2. Halaman 106-115.

Kemendiknas (2010). Pedoman pendidikan budaya karakter bangsa. Jakarta: Balitbang Pusat Kurikulum.

Krippendorff. (1980). Content analysis: an introduction to its metodology. Beverly Hils, California: Sage Publication Pld.

Samani, M., \&Hariyanto. (2013) Konsep dan model pendidikan karakter. Bandung: Rosda.

Wardhani, K. (8-10 November 2010) Peran guru dalam pendidikan karakter menurut konsep pendidikan ki hadjar dewantara. Proceding of The $4^{\text {th }}$ Internasional Conference on Teachers Education: Join Conference UPI\&UPSI Bandung. http://file.upi.edu/Direktori/PROCEEDING/UPIUPSI/2010/Book_2/PERAN_GURU_DALAM _PENDIDIKAN_KARAKTER_MENURUT_KONSEP_PENDIDIKAN_KI_HADJAR_DEWA NTARA.PDF.

Widiyatmaka, J., Edy T.,S.,, Sugeng N., (2013) Nilai pendidikan karakter dalam film sang kiai. Jurnal Mudra. Vol. 34. No. 1. Hlm. 73-79.

Wijayanti, D., \& Wachid P. (2019) Pendidikan Karakter melalui model pembelajaran kreatif bagi Siswa Sekolah Dasar (Studi SDN 2 Mendungan Yogyakarta). Jurnal Taman Cendekia. Vol 3. No. 1. Halaman 276-282.

Nussa Oficial. (23 Mei 2019) Baik itu Mudah. https://www.youtube.com/watch?v=sghAqhta08E

Zuchdi, D. (2009) Humanisasi pendidikan: menemukan kembali pendidikan yang manusiawi. Jakarta: Bumi Aksara. 